\title{
Learning Heat and Its Transfer with Power Point Learning Media for Grade V Students of Elementary School
}

\section{Dini Rozali1*, Zaka Hadikusuma Ramadan²}

1,2 Primary school teacher education program, Riau Islamic University, Riau, Indonesia

\section{ART I CLE INFO}

Article history:

Received April 02, 2021

Revised April 11, 2021

Accepted May 01, 2021

Available online May 25, 2021

Kata Kunci:

Media Pembelajaran Powerpoint

Keywords:

Learning media

PowerPoint

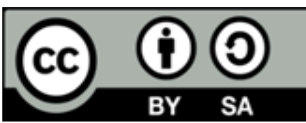

This is an open access article under the CC BY-SA license.

Copyright $(2021$ by Author. Published by Universitas Pendidikan Ganesha.

\begin{abstract}
A B S T R A K
Saat ini penggunaan media sebagai salah satu komponen pembelajaran belum sepenuhnya digunakan dan dikembangkan sesuai dengan kebutuhan, karakteristik dan kondisi saat ini serta proses pembelajaran guru terpaku hanya pada buku teks siswa. tujuan penelitian ini adalah untuk mengembangkan media pembelajaran Powerpoint untuk pembelajaran 3,4 dan 5 pada tema 6 "Panas dan Perpindahannya" Subtema 1 "Suhu dan Kalor" untuk siswa kelas V Sekolah Dasar. jenis penelitian adalah $R \& D$ dengan model pengembangan $4 D$ dengan tahapan penelitian pengembangan yaitu Define, Design, Development, and Dissemination. Namun pada pelaksanaannya penelitian ini dibatasi hingga uji validasi produk yang dilakukan pada tahap Development (pengembangan) produk. Subjek penelitian ini adalah 6 ahli, yang terdiri atas 2 ahli materi, 2 ahli bahasa dan 2 ahli desain serta siswa kelas V SD. Metode pengumpulan data yang dilakukan adalah wawancara dan lembar validasi. Analisis yang dilakukan adalah analisis kualitatif dan kuantitatif dari data wawancara dan lembar validasi. Hasil penelitian menyatakan bahwa media pembelajaran Powerpoint layak dilihat dari aspek materi, Bahasa, dan desain dengan skor rata-rata 93,7\% dengan kataori sangat valid. Jadi, media pembelajaran Powerpoint layak digunakan.
\end{abstract}

\section{A B S T R A C T}

Currently, media used as one of the learning components had not been fully used and developed according to the needs. The current characteristics and conditions and the teaching-learning process were fixated only on student textbooks. The purpose of this research was to develop Powerpoint learning media for learning 3,4 and 5 on theme 6 "Heat and Displacement," Sub-theme 1 "Temperature and Heat," for grade V elementary school students. However, in its implementation, this research is limited to product validation tests conducted at the development stage of the product. The subjects of this study were 6 experts, consisting of 2 material experts, 2 linguists and 2 design experts, and grade $\mathrm{V}$ elementary students. The data collection methods are interviews and validation sheets. The analysis was qualitative and quantitative analysis of interview data and validation sheets. The results stated that PowerPoint learning media was worth looking at in terms of materials, language, and design with an average score of $93.7 \%$, with a very valid category. So, Powerpoint learning media was worth using.

\section{INTRODUCTION}

Good learning is learning that allows students to learn to explore and build their knowledge actively. Meaningful learning will enable learners to experience and enhance emotional intelligence (Angela, 2014; Kostiainen et al., 2018). Meaningful learning will result from the learning process with a constructive approach and the learning process is regretted with significant concepts or issues that are being faced in the community (Kostiainen et al., 2018). Currently, learning is being faced by the COVID-19 pandemic global, which results in learning that should be done online(Khachfe et al., 2020) and all activities that involve many people such as seminars, workshops, co-ordinations and other activities are postponed and even canceled (Mishra et al., 2020; Oyedotun, 2020; Patricia, 2020; Sahu, 2020). During the COVID-19 pandemic, students must learn, and learning objectives must still be met. Overcome this, the learning that is done today is online learning.

Online learning is learning that is conducted in sync and asynchronously that provides opportunities for interaction of learners with learning resources without any space and time limits and is more flexible(Dong et al., 2020; Hwang et al., 2020; Kkese, 2020; Lage-Cala et al., 2020). The ability of students and educators to use technology greatly influences the success of online learning (Andel et al., 2020). In addition, online learning is strongly affected by the financial condition of the students and the facilities and infrastructure of online learning support (Rusli et al., 2020). Differences in students' financial needs and learning facilities require educators to prepare for learning when they are students. 
One very important component that educators have to prepare is Media. The media used in the learning process can help students to more easily understand the materials taught(Sukiyasa \&Sukoco, 2013; Tarwiti \&Wijayanti, 2018). The existence of learning media will make students happy and interested in learning, which impacts the acceptance of knowledge (Munawaroh et al., 2020). The use of teaching media must be adapted to learning, teaching materials, teaching methods, availability of tools needed, and the complexity of the materials delivered(Marwatoen, 2015). So, learning media will be very helpful learning process; therefore the development and use of media must be regretted with the curriculum, needs, and characteristics of learners.

However, currently, the use of media as one of the learning components has not been fully used and developed media that suits the current needs, characteristics, and conditions. Even though the school already has visiting facilities. However, these facilities have not been utilized to the maximum by teachers because teachers rarely use technology-based learning media such as Powerpoint. The teacher's learning process is fixated only on the student's textbooks. Teachers mostly use teaching materials from package books combined with general history reading books (Putri, 2020). Teachers rarely use Props and are not prepared by teachers(Nomleni \&Manu, 2018). The media used is conventional and less varied so that students are less interested in the learning process(Aini et al., 2017). So that students feel bored with learning, especially in learning that contains a lot of reading text. This causes students to be not interested in learning because they only read text. That way it causes students' learning outcomes become low. The percentage of students' KKM achievement in the previous year's learning is $65 \%$ with the number of students who reached KKM 28 students out of 43 students. If this condition is left to greatly impact the ability of learners in understanding the material being studied and this certainly has an impact on learning outcomes.

To solve the problem, it takes a learning medium that is easily accessible to students and does not require special skills is PowerPoint media. Powerpoint is an easy-to-use and relatively inexpensive medium because it does not require any raw materials other than tools to store data (Hidayatin, 2016; Prayitno \&Mardianto, 2020). The use of Powerpoint media can develop children's cognitive (Hikmah et al., 2021). Powerpoint has the advantage of being attractive, stimulating students, easy-to-understand visual display, easy for teachers, conditional, and practical (Jamilah, 2019; Wardani et al., 2017). Powerpoint can be done anytime and anywhere because students can operate it outside of school hours (Sakiah \&Effendi, 2021). Powerpoint can improve the quality of learning(Rahayu \&Hartati, 2016). These advantages are the reason for the development of PowerPoint media as a learning medium. Some studies state that media PowerPoint can improve learning outcomes (Astutik \&Zahroh, 2018; Faelasofi \&Mathematics, 2015; Marfuah et al., 2016; Shigli et al., 2016), as well as can increase the activeness of learners in the learning process (Azis, 2019). Research states that PowerPoint media developed by students is not yet worth using (Ishartono \&Nurcahyo, 2018). Researches conducted at elementary, junior high, and high school levels in universities positively impact different subjects.

The advantages of this Powerpoint media and the online learning conditions that are limited by the different facilities owned by each student are why this PowerPoint learning media was developed. The difference between this research and existing learning media developed is PowerPoint learning media for learning 3,4 and 5 on theme 6 "Heat and Displacement," Sub-theme 1 "Temperature and Heat," for grade V elementary school students. Powerpoint media developed consists of cover, presenting KD, Presenting objectives, presenting learning materials (in the form of images, videos and explanatory text), Interesting learning evaluation and cover. This study aims to develop Powerpoint learning media for 3,4 and 5 learning on theme 6 "Heat and Displacement," Sub-theme 1 "Temperature and Heat" for grade V elementary school students. This learning medium will be one of the alternatives that can be used to improve students' ability to understand the materials provided.

\section{METHOD}

The design of this research was development research using a qualitative approach and a quantitative approach. Qualitative approaches were used to obtain information from interview results, validation sheets, and documentation. At the same time, a quantitative approach was used to know the validity level of the product developed through assessment by validator experts. This development research resulted in a learning media product in the form of Powerpoint. In this thematic learning media development study, researchers chose to use a 4D development model (Sugiyono, 2015) with the development research stage, namely Define, Design, Development, and Dissemination. However, in its implementation, this research is limited to product validation tests conducted at the development stage of the product. 
Define stage was done to determine the things needed in the development of learning media. The determination was done by analyzing according to the characteristics of the student. At this stage, curriculum analysis, teacher analysis, and student analysis were carried out. Curriculum analysis was conducted to determine the basic competencies as well as the materials to be developed. The analysis of teachers and students was done to determine the criteria of PowerPoint learning media needed by students through interviews with teachers and students. Design stage, this Stage researchers set a medium that can improve cognitive ability, affective, and psychomotor students on the material. Researchers determine the learning media to be developed, namely PowerPoint learning media. Next, do the design of learning media in the form of Powerpoint with stages: Choosing a template that corresponds to the material to be developed and Determining the learning material that you wanted to develop into the learning media Powerpoint. Development Stage, at this stage, researchers develop the design made in the previous stage. The stages in this development are: 1) Reviewing the number of slides to be developed. 2) Modifying existing templates tailored to students' needs and according to their learning materials. 3) Reviewing materials to be developed into Powerpoint media. And Make edits on Powerpoint. After developing the Powerpoint learning media, then conduct a validation test stage by experts twice until the validation results of the validity level product were very valid and worth using without revision.

This research was conducted at SDN 115 Pekanbaru, located at Jl. Kaharuddin Nst No.266, Maharatu, Kec. Marpoyan Damai, Pekanbaru City, Riau. This research took place from November 2020 to April 2021. The data collected in this study were primary data and secondary data. Primary data was obtained directly to the source without intermediaries. In this study, primary data was obtained from interviews with grade $\mathrm{V}$ elementary teachers and media validation, including media experts, linguists, and thematic material experts. Secondary data was obtained from documents or files obtained from reliable sources. Secondary data includes relevant journals, articles, books and other sources. The data sources in this study were obtained from various sources, including validators consisting of media experts, linguists and thematic material experts. And the speaker of grade V elementary school teacher. In this developmental study, the subject of his research was validator experts to test the validity of the resulting product. Validator experts consist of three areas of expertise: media experts with two experts, linguists with two experts, and thematic material experts.

Data collection techniques were conducted by interview, validity sheet, and documentation. Interviews were conducted to students and teachers to find out the criteria of PowerPoint learning media that correspond to the characteristics of grade $\mathrm{V}$ elementary students according to the cognitive development of students. Validation sheet by using Likert scale with alternative answers: excellent (SB), good (B), enough (C), less (K), very less (SK). Documentation is used to research the form of images/photos at the time of the validation test. After developing the Powerpoint learning media, then conduct a validation test stage by experts twice until the validation results of the validity level product is very valid and worth using without revision. Data analysis techniques using qualitative and quantitative data analysis techniques. Qualitative data is obtained from opinions given by validator experts submitted on the validation sheet. The data were analyzed as the basis for product improvement, which was further developed into a valid product. Quantitative data in the form of value results submitted by validator experts. The data in the validation sheet was converted into interval data as a validation analysis of the developed product. The assessment data on the feasibility of learning media development products obtained from validator experts was analyzed descriptively. In determining the validity level of learning media, validation data is analyzed using percentage data analysis techniques. Determination of validity and product revision levels was seen in Table 1.

Table 1. Validity Level and Product Revision

\begin{tabular}{cc}
\hline Validaty Criteria & Percentage (\%) \\
\hline Not Valid & $0-20$ \\
Less Valid & $21-40$ \\
Valid Enough & $41-60$ \\
Valid & $61-80$ \\
Very Valid & $81-100$ \\
\hline
\end{tabular}

\section{RESULT AND DISCUSSION}

\section{Result}

The process of developing Powerpoint learning media was done using 4D development model (Define, Design, Development, and Dissemination)according to Thiagarajan (in Sugiyono, 2019: 37), but in this development, the development process was carried out with the limitations of the research stage 
only Define, Design, Development. Here were the stages of PowerPoint learning media development. Define stage At the define stage was carried out curriculum analysis, teacher analysis, and student analysis. Curriculum analysis, this stage analyzed core competencies, basic competencies, indicators, and materials developed into PowerPoint learning media. Curriculum analysis Curriculum analysis, at this stage, was carried out to analyze core competencies, basic competencies, indicators, and materials developed into PowerPoint learning media. In learnings 3, 4 and 5 there were three subjects to be studied. Subjects in learning 3 and 4 are Bahasa Indonesia, PPKn, and IPS, in the study of 5 subjects are IPA, Bahasa Indonesia and SBdP. Results of KD analysis and initiators are described in table 2.

Analysis needs to be obtained interview results stated that students and teachers received learning media that attracts their attention in the learning process was by the attractiveness of images, as well as the presence of video in the delivery of materials and in terms of design more use neutral colors so that the material conveyed clearly. And for grade $\mathrm{V}$ elementary students were in the age range of 11-12 years, then the age of 11-12 years was classified to the 3rd stage, the concrete operational stage. The child was mature enough to use logical thinking or surgery at this stage, but only for physical objects. To present a physical object to a material, the teacher needs to use the media as an intermediary tool. Then one of the media that was efficient and attracted students' attention was the use of PowerPoint learning media. Following the interviews with grade $\mathrm{V}$ elementary teachers, the presentation of PowerPoint learning media must be real or concrete to provide a hands-on experience for students. By displaying images and videos that look real. As well as the combination of writing colors and background did not stand out, so that the material presented remains the center of attention of students.

Table 2. Basic Competencies and Learning Indicators 3, 4 and 5

\begin{tabular}{|c|c|c|c|}
\hline \multicolumn{2}{|r|}{ Basic Competence } & \multicolumn{2}{|r|}{ Indicators } \\
\hline \multicolumn{4}{|c|}{ Bahasa } \\
\hline \multirow[t]{2}{*}{3.3} & $\begin{array}{l}\text { Summarizes explanatory text on print } \\
\text { or electronic media. }\end{array}$ & 3.3 .1 & $\begin{array}{l}\text { Interpreting explantation text in print or } \\
\text { electronic media }\end{array}$ \\
\hline & & 3.3.2 & $\begin{array}{l}\text { Conceptualize explantation text on print or } \\
\text { electronic media }\end{array}$ \\
\hline 4.3 & $\begin{array}{l}\text { Presents a summary of explanatory } \\
\text { text from print or electronic media } \\
\text { using standard vocabulary and } \\
\text { effective sentences verbally, written, } \\
\text { and visually. }\end{array}$ & 4.3.1 & $\begin{array}{l}\text { Writes the explantation text of the displayed } \\
\text { video. }\end{array}$ \\
\hline
\end{tabular}

3.2 Understand the rights, obligations and responsibilities of citizens in daily life.

3.2 .1

3.2 .2

3.2 .3

3.2 .4

4.2 Explaining the rights, obligations, and responsibilities as a citizen in daily life.

\section{Social Science}

3.2 Analyzing the form of human interaction with the environment and its influence on Indonesian society's social, cultural, and economic development.

4.2 Menyajikan hasil analisis tentang interaksi manusia dengan lingkungan dan pengaruhnya terhadap pembangunan sosial, budaya, dan ekonomi masyarakat Indonesia.

\section{Natural Science}

3.6 Menerapkan konsep perpindahan kalor dalam kehidupan sehari-hari
Exploring the rights of citizens in everyday life Implementing the right as a citizen in daily life Digging up information obligations as citizens in daily life

Implementing obligations as citizens in daily life

4.2.1 Explaining the rights, obligations, and responsibilities as a citizen in daily life

3.2.1 Mengklasifikasikan bentuk interaksi manusia dengan lingkungan alam.

3.2.2 Menelaah bentuk interaksi manusia dengan lingkungan alam

4.2.1 Menganalisis interaksi manusia dengan lingkungannya

3.6.1 Exploring the concept of heat transfer in everyday life

3.6.2 Exploring the concept of heat transfer in everyday life 


\begin{tabular}{llll}
\hline \multicolumn{1}{c}{ Basic Competence } & \multicolumn{1}{c}{ Indicators } \\
\hline 4.6 & $\begin{array}{l}\text { Report observations about heat } \\
\text { transfer. }\end{array}$ & 4.6 .1 & Report observations about heat transfer. \\
\hline Art \& Culture & 3.2 .1 & Studying the pitch ladder \\
\hline 3.2 & $\begin{array}{l}\text { Report observations about heat } \\
\text { transfer. }\end{array}$ & 4.2 .1 & Practice the use of pitch ladders \\
$4.2 \quad \begin{array}{l}\text { Sing songs in various charts with } \\
\text { musical accompaniment. }\end{array}$ & & \\
\hline
\end{tabular}

Design Stage, this stage was the second stage conducted by researchers. Researchers determine the template design used in the development of learning media later and choose the learning materials developed into PowerPoint learning media at the design stage. Some of the templates used were shown in figures 1, 2 and 3. Furthermore, researchers designed the material developed into PowerPoint media to present interesting and concrete material on images and videos and not monotonous in the book's text only.
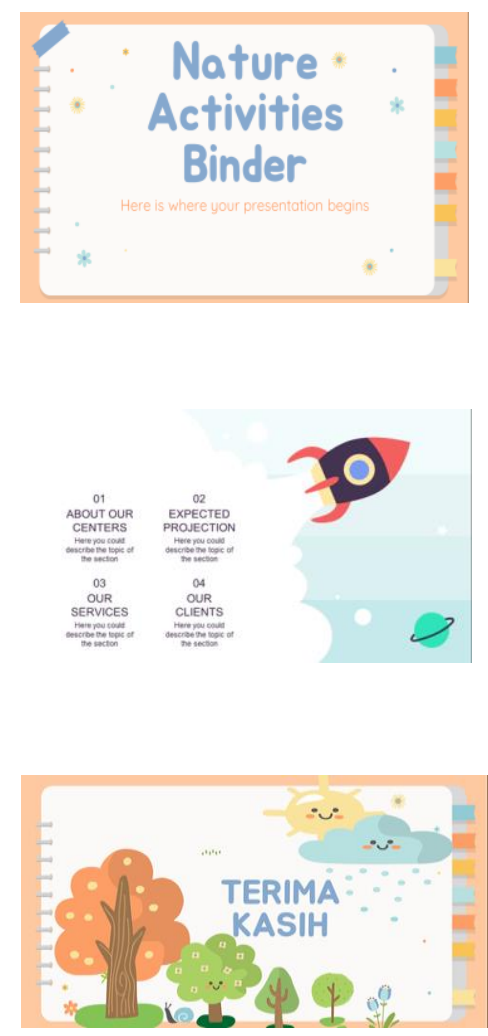

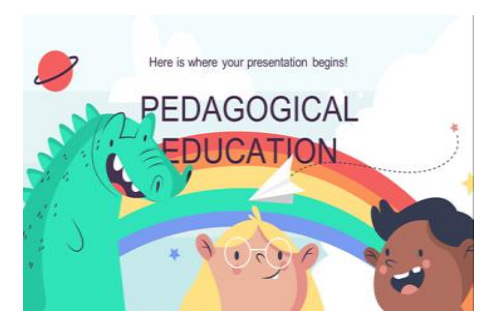

Figure 1. Cover

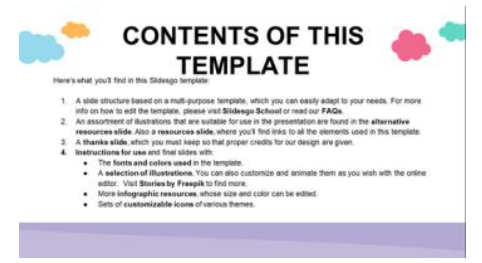

Figure 2. Contents

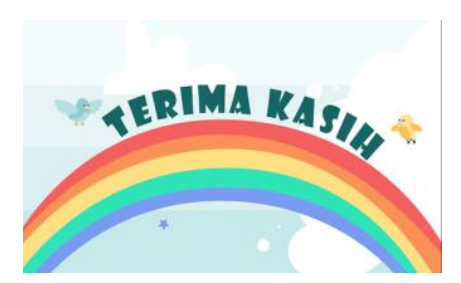

Figure 3. Closing
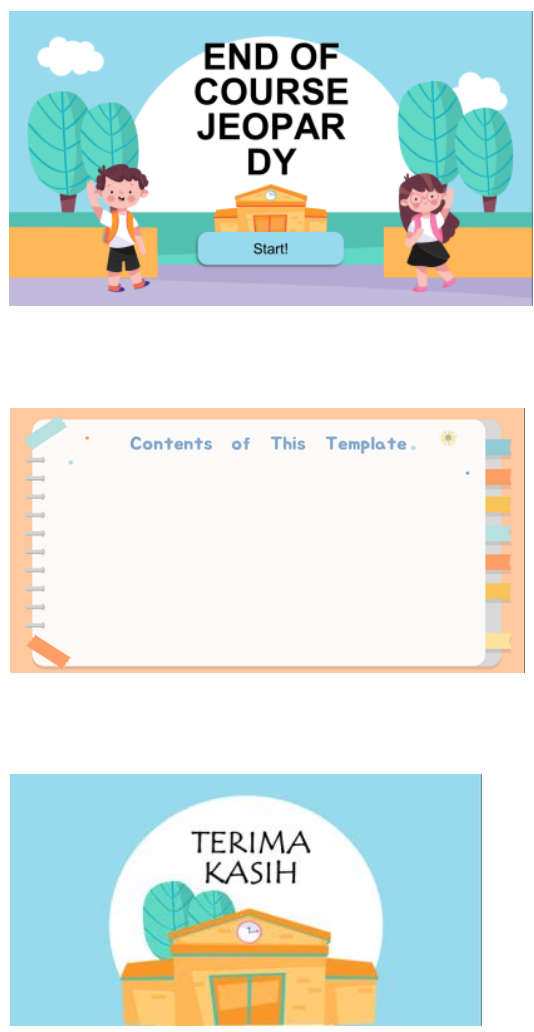

Development Stage, This Stage was the last stage in this development research. At this stage, researchers develop PowerPoint media with a predetermined template at the previous stage by paying attention to the components that must exist in PowerPoint media such as there was a cover, presenting basic competencies, presenting objectives, presenting learning materials (in the form of images, videos and explanatory text), interesting learning evaluations and covers. The following was a display of PowerPoint learning media for learning 3, 4 and 5 after going through the development stages of material preparation and layout an arrangement in PowerPoint shown figures 4,5 and 6.
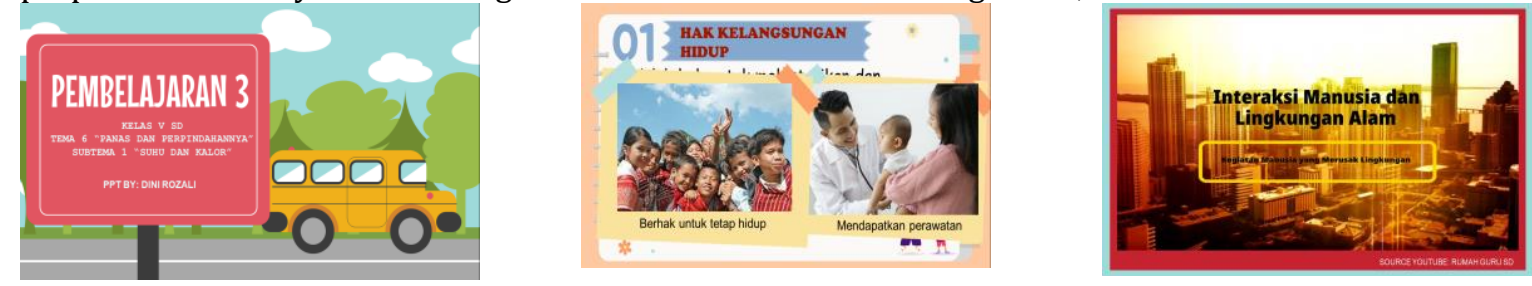

Figure 4. Powerpoint Learning Media 3 

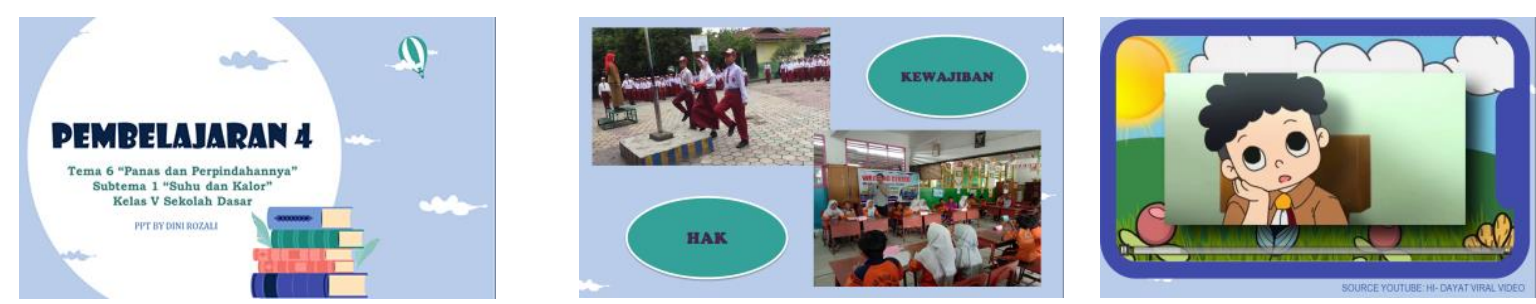

Figure 5. Powerpoint Learning Media 4
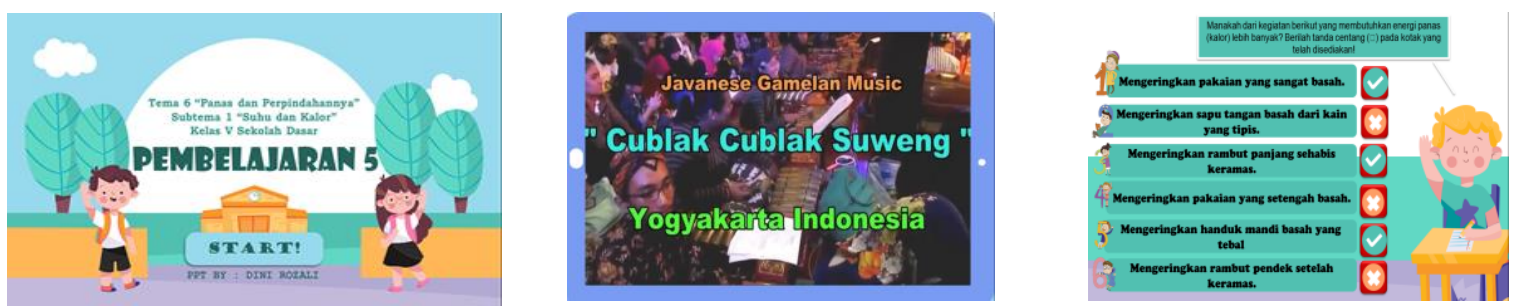

Figure 6. Powerpoint Learning Media 5

After developing the three PowerPoint learning media, the next stage was to conduct validation tests conducted by validators with three areas of expertise: linguists, media experts, and materials experts. Here were the validation results from each validator in each area of expertise: Product Validation and Revision by Linguist. The assessment was conducted on the linguistic aspects of the PowerPoint learning media that had been developed. The results of the first validation test for the language aspect obtained an average score from both experts of $72 \%$ with a validity level of valid. The input was the first letter of the person's name was written in capital letters. After making revisions, the researchers then submitted a second validation to both experts. Validation test assessment for the second after making improvements according to comments and expert advice obtained an average rating of 93\% with a very valid validity rate. And both experts commented that PowerPoint learning media was worth using without revisions in grade $\mathrm{V}$ elementary students with a category of validity level of media was very valid.

The results of the first validation test for the 4th study reached an average score of $84 \%$ with a very valid validity level. Still, there were some improvements so that the researchers continued to make revisions and validation tests of the second. In the second validation test, a modification was made to increase the value for the second validator because the previous value was still at the valid level only. After a thorough improvement due to the absence of advice or comments from experts, the score for the second validation test was $93 \%$, with the validity level reaching a very valid level. Then this learning medium is worth using. The results of the first validation test for learning 5 gained an average of $78 \%$ with a valid validity rate only. As for the input from experts, the word should be changed to the question word 'what conclusions do you get from the video?' sentences became more effective and not rambling". After making revisions, the researchers then submitted a second validation to both experts. After the second validation test was conducted to both experts, the assessment of learning media on the language aspect with the average value obtained was $93 \%$ with a valid level of validity. Thus, PowerPoint learning media is worth using.

The results of material validation obtained assessment on the material aspect for learning 3 by $81 \%$ with a very valid level of validity. After checking the basic competencies in Indonesian language subjects were correct for learning 4 and 5 no comments. After making revisions, the researchers then submitted a second validation to both experts for the three learning media, namely the second validation for the three powerpoint learning media got an average of $88 \%$ with a very valid validity level and the media is eligible for use without revision in grade $\mathrm{V}$ elementary students.

Media validation results obtained a value for learning media 3 on average $85 \%$ with a very valid validity level, but there are some comments. Adapin enter it is 1) reduce the use of too ordinary animations because for grade 5 students, they were no longer interested in animations that were too rigid. 2) the right to protection material was replaced with a more relevant photo to the student's life, and 3) in the evaluation question sentence was corrected again so as not to cause misinterpretation for the student. Based on these comments, researchers improved powerpoint learning media by changing ppt templates to make the animations more interesting. After improving the learning media PowerPoint, the second validation with the second validation result is $90 \%$ with a very valid validity level and is eligible to be used to grade $\mathrm{V}$ elementary students without revision. The average gain for the first validation result is $92 \%$ 
with a very valid validity rate. For the 4 th lesson for the 2 nd validator was worth using without revision. Still, for the first validator, some shortcomings must be fixed according to the suggestions and comments were given that the cover was too crowded, the font replaces it with a more relaxed and set the letter spacing to be more stretched. After making improvements, the second validation result was $97 \%$, with a very valid validity level so that the learning media was eligible for grade $\mathrm{V}$ elementary students. The average score for learning media PowerPoint learning 5 was $89 \%$ accompanied by some comments from both experts. Comments are templates that are used too feminine and less universal and avoid using animations that were too rigid. Based on these comments, some experts agreed that the template that became the reference is the 5th learning because it was considered an appropriate template for education in elementary school. So the researchers did not change the template to reduce the use of feminine colors in the previous design. After making revisions following the suggestions and comments of both validators, then a second validation with a rating result of $94 \%$ with a category was very valid. Thus, learning media can already be used to grade $\mathrm{V}$ elementary students in the learning process. in brief, the validation of PowerPoint media developed as described in Table 3.

Table 3. Validation Result of PowerPoint Media

\begin{tabular}{ccccccc}
\hline \multirow{2}{*}{ Scored Aspect } & \multicolumn{6}{c}{ Rating Percentage (\%) } \\
\cline { 2 - 7 } & \multicolumn{2}{c}{ Learning 3 } & \multicolumn{2}{c}{ Learning 4 } & \multicolumn{2}{c}{ Learning 5 } \\
\cline { 2 - 7 } & $\mathbf{1}$ & $\mathbf{2}$ & $\mathbf{1}$ & $\mathbf{2}$ & $\mathbf{1}$ & $\mathbf{2}$ \\
\hline Language Aspect & $72 \%$ & $93 \%$ & $84 \%$ & $93 \%$ & $78 \%$ & $93 \%$ \\
Material Aspect & $81 \%$ & $95 \%$ & $81 \%$ & $95 \%$ & $81 \%$ & $95 \%$ \\
Media Aspect & $85 \%$ & $90 \%$ & $92 \%$ & $97 \%$ & $89 \%$ & $94 \%$ \\
\hline Mean & $\mathbf{7 9 \%}$ & $\mathbf{9 2} \%$ & $\mathbf{8 5 \%}$ & $\mathbf{9 5 \%}$ & $\mathbf{8 2} \%$ & $\mathbf{9 4} \%$ \\
\hline
\end{tabular}

In the 3rd study for the first validation test, results gained an average of $79 \%$. Then a second validation test was conducted, and the value was obtained by $92 \%$. The increase in assessment on PowerPoint learning media for learning 3 was $21 \%$. With the category of validity level of the product from the previously valid to be very valid. In the study 4 score acquisition for the first validation of $85 \%$ with a very valid category. But the researchers still made some improvements so that the second validation obtained a value of $95 \%$. Learning 5 averaged $82 \%$, with a very valid validity level in the first validation test. In the second validation test, the average gain was $94 \%$, with a very valid category. Thus PowerPoint learning media is worth using for grade $\mathrm{V}$ elementary students. All three PowerPoint learning media are eligible to be used without revisions with validity criteria and achieving a very valid level by conducting validation tests twice. However, this study was limited to the validation test stage so that no trials were conducted on students in elementary school.

\section{Discussion}

The results showed that the PowerPoint media developed was worth using. This was inseparable from the development stage done. The first stage is the analysis stage of this stage will provide an analysis of the need for learning media that can increase students' activeness in the middle of the pandemic. The media needed by elementary school children was a medium that combines images, sounds and sounds that are interesting. Interesting media will be able to improve the ability of students to understand the materials provided. and currently, the media needed was a media that can be accessed anywhere and can be used without high technological facility, considering the financial capabilities of different parents. The learning medium that can be used was Powerpoint media. Powerpoint was an easy-to-use and relatively inexpensive medium because it does not require any raw materials other than tools to store data(Hidayatin, 2016; Prayitno \&Mardianto, 2020). The use of Powerpoint media can develop children's cognitive (Hikmah et al., 2021). Powerpoint has the advantage of being attractive, stimulating students, easy-to-understand visual display, easy for teachers, conditional, and practical(Jamilah, 2019; Wardani et al., 2017). Powerpoint can be done anytime and anywhere because students can operate it outside of school hours (Sakiah \&Effendi, 2021). Powerpoint can improve the quality of learning (Rahayu \&Hartati, 2016). Selian it to make a good media needs to be done curriculum analysis and materials because a good media was a medium in line with the curriculum, materials, and character of learners. Producing good media requires teachers to develop teaching materials that are in line with the needs of learners, curriculum demands, and line with the character of learners (Andani \&Yulian, 2018; Cloonan \&Fingeret, 2020; Mayarnimar \&Taufina, 2017; Weriyanti et al., 2020). So, learning media will be a beneficial learning 
process; therefore, the development and use of media must be regretted with the curriculum, needs, and characteristics of learners.

The second stage of this research design, the design of this media, was regretted with the child's character. Designing a teaching material will help students understand the material more easily. In addition, the selection of colors, letters, and characters in a medium will affect students' understanding. Color, font size, and typeface should be made more attractive (Riwu et al., 2018), making the materials that are divided more feasible to use. Development of teaching materials that are following the demands of the curriculum with the needs of students, namely teaching materials that were following the characteristics and environment of students (Mayarnimar \&Taufina, 2017; Weriyanti et al., 2020). The picture on the media that is in line with the material can attract students' attention in the learning process (Firdaus \&Mukhaiyar, 2021). Image media feed can motivate students (Dewi et al., 2018; Nurjannah, 2018). Color, font size developed determines the feasibility of a medium.

At this stage of powerpoint media, the development stage is declared valid both in terms of materials, language, and design. The media is valid if it meets the material requirements, easy-tounderstand language, and design in line with its character and attractiveness (Irman \&Waskito, 2020; Lestar, 2021). Media that is in line with the character will be able to say learners' motivation and learning outcomes. The media used in the learning process can help students to more easily understand the materials taught (Sukiyasa \&Sukoco, 2013; Tarwiti \&Wijayanti, 2018). The existence of learning media will make students happy and interested in learning, which impacts the acceptance of knowledge (Munawaroh et al., 2020). The use of teaching media must be adapted to learning, teaching materials, teaching methods, availability of tools needed, and the complexity of the materials delivered (Marwatoen, 2015). So, learning media will be a beneficial learning process; therefore, the development and use of media must be regretted with the curriculum, needs, and characteristics of learners. The results of this study are reinforced by the results of research that states that PowerPoint media can improve learning outcomes (Astutik \&Zahroh, 2018; Faelasofi \&Mathematics, 2015; Marfuah et al., 2016; Shigli et al., 2016), as well as can increase the activeness of learners in the learning process (Azis, 2019). Research states that PowerPoint media developed by students is not yet worth using (Ishartono \&Nurcahyo, 2018). Studies conducted at elementary, junior high, and high school levels in universities with different subjects positively impact.

The explanation was given that the PowerPoint media used was worth using and in line with the needs and conditions during limited online learning. The advantages of this Powerpoint media and the online learning conditions that were limited by the different facilities owned by each student was why this PowerPoint learning media was developed. The difference between this research and existing learning media developed is PowerPoint learning media for learning 3,4 and 5 on theme 6 "Heat and Displacement" Sub-theme 1 "Temperature and Heat" for grade V elementary school students. Powerpoint media developed consists of cover, presenting KD, Presenting objectives, presenting learning materials (in the form of images, videos, and explanatory text), Interesting learning evaluation, and cover. The design developed in line with the characteristics of students and the current needs of learning media are easy, cheap, and do not require a lot of supporting facilities.

\section{CONCLUSION}

Powerpoint learning media was declared valid with a category that was very worthy of judging from the material aspect, language, and design. This media can be used as a learning resource. Media with good content, easy-to-understand language, and attractive design can help students understand the material.

\section{REFERENCES}

Aini, N., Siti, A., \& Yulia, C. (2017). Pengaruh Penggunaan Audio Visual Pada Pencapaian "Kompetensi Dasar Mengolah Stock, Soup Dan Sauce" Siswa Smk 3 Cimahi. Media Pendidikan, Gizi, Dan Kuliner, 2(1), 24-32.

Andel, S. A., de Vreede, T., Spector, P. E., Padmanabhan, B., Singh, V. K., \& Vreede, G. J. de. (2020). Do social features help in video-centric online learning platforms? A social presence perspective. Computers in Human Behavior, 113(April), 106505. https://doi.org/10.1016/j.chb.2020.106505.

Angela, T. (2014). Challenges to Meaningful Learning in Social Studies - The Key Competences as an Opportunity to Students' Active Participation. Procedia - Social and Behavioral Sciences, 128, 192197. https://doi.org/10.1016/j.sbspro.2014.03.142.

Astutik, S. D., \& Zahroh, U. (2018). Efektivitas Model Cycle Learning Menggunakan Media Powerpoint 
terhadap Hasil Belajar Materi Garis dan Sudut Kelas VII MTsN Karangrejo. Jurnal Tadris Matematika, 1(1), 35-42. https://doi.org/10.21274/jtm.2018.1.1.35-42.

Azis. (2019). Penggunaan Media Interaktif Berbasis Geogebra dan Powerpoint Untuk Meningkatkan Keaktifan dan Hasil Belajar Peserta Didik Pada Materi Pegal di Kelas VIII1 SMPN 3 Tanete Rilau. Jurnal Studi Guru Dan Pembelajaran, 2(3), 221-229. https://doi.org/10.30605/jsgp.2.3.2019.8.

Dong, C., Cao, S., \& Li, H. (2020). Young children's online learning during COVID-19 pandemic: Chinese parents' beliefs and attitudes. Children and Youth Services Review, 118(August), 105440. https://doi.org/10.1016/j.childyouth.2020.105440.

Faelasofi, R., \& Matematika, P. (2015). Penggunaan Media Pembelajaran Microsoft Office. E-DuMath, 1(1), 17-29. https://scholar.google.com/scholar.

Hidayatin, N. (2016). Pengaruh Pendekatan Contextual Teaching and Learning (Ctl) Terhadap Hasil Belajar Matematika. Buana Matematika: Jurnal Ilmiah Matematika Dan Pendidikan Matematika, 6(1:), 49-56. https://doi.org/10.36456/buanamatematika.v6i1:.377.

Hikmah, N., Eka Selvi Handayanis, \& I Wayan Edi Arsawan. (2021). Pelatihan Media Internet dan Powerpoint bagi Anak-anak dan Warga Menuju Kampung Cerdas. Bhakti Persada, 7(1), 59-65. https://doi.org/10.31940/bp.v7i1.2352.

Hwang, G. J., Wang, S. Y., \& Lai, C. L. (2020). Effects of a social regulation-based online learning framework on students' learning achievements and behaviors in mathematics. Computers and Education, 160, 104031. https://doi.org/10.1016/j.compedu.2020.104031.

Ishartono, N., \& Nurcahyo, A. (2018). Studi Kasus Media Pembelajaran Matematika Berbasis Powerpoint Karya Mahasiswa Semester 6 Prodi Pendidikan Matematika Ums. JINoP Ournal Inovasi Pembelajaran), 4(2), 141. https://doi.org/10.22219/jinop.v4i2.6624.

Jamilah, N. (2019). Pengembangan Media Pembelajaran Power Point Ispring Presenter Pada Materi Kosakata Bahasa Arab Peserta Didik Kelas V MI Tarbiyatul Athfal Lampung Timur. Al Mahāra: Jurnal Pendidikan Bahasa Arab, 5(1), 141-154. https://doi.org/10.14421/almahara.2019.051-08.

Khachfe, H. H., Chahrour, M., Sammouri, J., Salhab, H. A., Makki, B. E., \& Fares, M. Y. (2020). An Epidemiological Study on COVID-19: A Rapidly Spreading Disease. Cureus, 12(3). https://doi.org/10.7759/cureus.7313.

Kkese, E. (2020). McGurk effect and audiovisual speech perception in students with learning disabilities exposed to online teaching during the COVID-19 pandemic. Medical Hypotheses, 144(July), 110233. https://doi.org/10.1016/j.mehy.2020.110233.

Kostiainen, E., Ukskoski, T., Ruohotie-Lyhty, M., Kauppinen, M., Kainulainen, J., \& Mäkinen, T. (2018). Meaningful learning in teacher education. Teaching and Teacher Education, 71, 66-77. https: //doi.org/10.1016/j.tate.2017.12.009.

Lage-Cala, S., Folgueras-Díaza, M. B., Alonso-Hidalgoa, M., García-Menéndezb, D., \& Fernández-Garcíab, F. J. (2020). Investigation of the effectiveness of online learning tools for energy performance certificates preparation. Energy Reports, 6, 609-614. https://doi.org/10.1016/j.egyr.2019.09.034.

Marfuah, S., Zulkardi, Z., \& Aisyah, N. (2016). Pengembangan Media Pembelajaran Menggunakan Powerpoint Disertai Visual Basic for Application Materi Jarak Pada Bangun Ruang Kelas X. Jurnal Gantang, 1(1), 45-53. https://doi.org/10.31629/jg.v1i1.5.

Marwatoen, F. (2015). Pengaruh Media Presentasi dan Komik dalam Pembelajaran Biologi terhadap Hasil Belajar ditinjau dari Motivasi Siswa. Prisma Sains: Jurnal Pengkajian Ilmu Dan Pembelajaran Matematika Dan IPA IKIP Mataram, 3(2), 71. https://doi.org/10.33394/j-ps.v3i2.976.

Mishra, D. L., Gupta, D. T., \& Shree, D. A. (2020). Online Teaching-Learning in Higher Education during Lockdown Period of COVID-19 Pandemic. International Journal of Educational Research Open, August, 100012. https://doi.org/10.1016/j.ijedro.2020.100012.

Munawaroh, H., Widiyani, A. Y. E., \& Muntaqo, R. (2020). Pengembangan Multimedia Interaktif Tema Alam Semesta pada Anak Usia 4-6 Tahun. Jurnal Obsesi : Jurnal Pendidikan Anak Usia Dini, 5(2), 11641172. https://doi.org/10.31004/obsesi.v5i2.619.

Nomleni, F. T., \& Manu, T. S. N. (2018). Pengembangan Media Audio Visual dan Alat Peraga dalam Meningkatkan Pemahaman Konsep dan Pemecahan Masalah. Scholaria: Jurnal Pendidikan Dan Kebudayaan, 8(3), 219-230. https://doi.org/10.24246/j.js.2018.v8.i3.p219-230.

Oyedotun, T. D. (2020). Sudden change of pedagogy in education driven by COVID-19: Perspectives and evaluation from a developing country. Research in Globalization, 2(June), 100029. https://doi.org/10.1016/j.resglo.2020.100029.

Patricia, A. (2020). College Students' Use and Acceptance of Emergency Online Learning Due to COVID-19. International Journal of Educational Research Open, 100011. https://doi.org/10.1016/j.ijedro.2020.100011.

Prayitno, P., \& Mardianto, M. F. F. (2020). Peningkatan Hasil Evaluasi Pembelajaran Daring Saat Pandemi 
Covid-19 berdasarkan Media Powerpoint Interaktif. MUST: Journal of Mathematics Education, Science and Technology, 5(2), 171-181. http://journal.umsurabaya.ac.id/index.php/matematika/article/view/6119/3464.

Putri, A. E. (2020). Analisis Kebutuhan Bahan Ajar Berbasis Literasi Digital Nilai-Nilai Kearifan Lokal pada Tradisi Saprahan di Pontianak. Yupa: Historical Studies Journal, 3(1), 1-7. https://doi.org/10.30872/yupa.v3i1.132.

Rahayu, H., \& Hartati, S. (2016). Peningkatan Kualitas Pembelajaran Ipa Melalui Strategi Belajar Pq4R Berbantuan Media Powerpoint. Phenomenon: Jurnal Pendidikan MIPA, 6(1), 35-44. https://doi.org/10.21580/phen.2016.6.1.943.

Rusli, R., Rahman, A., \& Abdullah, H. (2020). Student perception data on online learning using heutagogy approach in the Faculty of Mathematics and Natural Sciences of Universitas Negeri Makassar, Indonesia. Data in Brief, 29, 105152. https://doi.org/10.1016/j.dib.2020.105152.

Sahu, P. (2020). Closure of Universities Due to Coronavirus Disease 2019 (COVID-19): Impact on Education and Mental Health of Students and Academic Staff. Cureus, 2019(4), 4-9. https://doi.org/10.7759/cureus.7541.

Sakiah, N. A., \& Effendi, K. N. S. (2021). Analisis Kebutuhan Multimedia Interaktif Berbasis PowerPoint Materi Aljabar Pada Pembelajaran Matematika SMP. JP3M (Jurnal Penelitian Pendidikan Dan Pengajaran Matematika), 7(1), 39-48. https://doi.org/10.37058/jp3m.v7i1.2623.

Shigli, K., Agrawal, N., Nair, C., Sajjan, S., Kakodkar, P., \& Hebbal, M. (2016). Use of PowerPoint presentation as a teaching tool for undergraduate students in the subject of gerodontology. Journal of Indian Prosthodontist Society, 16(2), 187-192. https://doi.org/10.4103/0972-4052.167940.

Sugiyono. (2015). Metode Penelitian Kuantitatif Kualitatif. Alfabeta.

Sukiyasa, K., \& Sukoco, S. (2013). Pengaruh media animasi terhadap hasil belajar dan motivasi belajar siswa materi sistem kelistrikan otomotif. Jurnal Pendidikan Vokasi, 3(1), 126-137. https://doi.org/10.21831/jpv.v3i1.1588.

Tarwiti, C., \& Wijayanti, A. (2018). Pengembangan Media Kotak Ajaib Pada Mata Pelajaran IPA Materi Pesawat Sederhana Siswa Kelas V Sekolah Dasar. Jurnal Sekolah (JS), 2(9), 308-314. https: //doi.org/10.1017/CB09781107415324.004.

Wardani, R. F. A. K., Rifai, M., \& Mandalawati, T. K. (2017). Efektivitas Model Pembelajaran Clis Berbantuan Media Slide Powerpoint Terhadap Hasil Belajar IPA. Premiere Educandum: Jurnal Pendidikan Dasar Dan Pembelajaran, 7(02), 104. https://doi.org/10.25273/pe.v7i2.1596. 